\title{
Comparative Study of the Effects of Annona muricata and Tapinanthus globiferus Extracts on Biochemical Indices of Diabetic Rats
}

\author{
Atanu FO',*, Avwioroko OJ ${ }^{2}$, llesanmi OB ${ }^{3}$, Oguche $\mathrm{M}^{1}$
}

Atanu $\mathrm{FO}^{1, *}$, Avwioroko $\mathrm{OJ}^{2}$, Ilesanmi $\mathrm{OB}^{3}$, Oguche $\mathrm{M}^{1}$

'Department of Biochemistry, Faculty of Natural Sciences, Kogi State University, Anyigba, NIGERIA.

${ }^{2}$ Department of Chemical Sciences, College of Natural Sciences, Redeemer's University, Ede, Osun State, NIGERIA.

${ }^{3}$ Department of Biological Sciences, Faculty of Science, Federal University Otuoke, Bayelsa State, NIGERIA.

\section{Correspondence}

\section{Dr. Francis O. Atanu}

Department of Biochemistry, Faculty of Natural Sciences, Kogi State University, Anyigba, NIGERIA.

E-mail: atanufo@gmail.com

History

- Submission Date: 12-07-2019;

- Review completed: 31-07-2019;

- Accepted Date: 23-08-2019.

DOI : 10.5530/pj.2019.11.211

Article Available online

http://www.phcogj.com/v11/i6

\section{Copyright}

(c) 2019 Phcogj.Com. This is an openaccess article distributed under the terms of the Creative Commons Attribution 4.0 International license.

\begin{abstract}
Introduction: Annona muricata and Tapinanthus globiferus (mistletoe) are medicinal plants used in traditional medicine to combat an array of human diseases. However, there is dearth of scientific prove for the activity of these plants in the management of non-infectious human diseases such as cancer, insomnia, hypertension, ulcers and diabetes. Method: The present study was designed to assess comparatively the effects of methanol extracts of Annona muricata (AME) and Tapinanthus globiferus (TGE) on biochemical indices of alloxan induced diabetic rats. The animals were allocated to eight (8) groups, group I were normal non-diabetic rats, group II (diabetic untreated group), group III treated with metformin alone, groups IV \& V were diabetic rats treated with AME at dose of concentration $200 \mathrm{mg} / \mathrm{kg} \mathrm{BW} \mathrm{\&} 400 \mathrm{mg} / \mathrm{kg} \mathrm{BW}$ respectively, groups VI \& VII were diabetic rats treated with $200 \mathrm{mg} / \mathrm{kg}$ BW \& $400 \mathrm{mg} / \mathrm{kg} \mathrm{BW}$ of TGE respectively. Group VIII were diabetic rats treated with AME + TGE at concentration of $200 \mathrm{mg} / \mathrm{kg}$ BW each. Concentrations of serum total cholesterol (TC), high density lipoprotein (HDL), triglyceride (TG) of alloxan diabetic rats, creatinine and urea were assayed after 21 days of the respective treatments. Results: Diabetic untreated rats had significant increase $p<0.05$ in TC, TG, urea and creatinine compared to normal control group as opposed to the significant decrease observed for $\mathrm{HDL}$ in diabetic rats. However, treatment of diabetic rats with AME and TGE significantly suppressed $(p<0.05)$ the concentrations of TC, TG and creatinine when compared with the diabetic untreated rats. A similar trend was observed for the calculated atherogenic index of treated rats when compared with diabetic untreated rats. Interestingly, co-administration of AME + TGE improved the biochemical indices of diabetic rats better than using each plant separately. Conclusion: The results of this study suggest that AME and TGE could offer some benefits in the management of diabetic complications especially with regard to cardiac and renal health.
\end{abstract}

Key words: Alloxan, Annona muricata, Diabetes, Mistletoe, Tapinanthus globiferus.

\section{INTRODUCTION}

Diabetes mellitus is the most common metabolic disorder of the endocrine system. It is characterised by defects in insulin secretion or insensitivity of insulin receptors categorized as type I and type II diabetes respectively. ${ }^{1}$ Either of these metabolic anomalies is characterised by impaired metabolism of carbohydrates and other energy-yielding fuel compounds such as lipids and proteins. This results in diabetic complications including but not limited to hyperglycemia, retinopathy, dyslipidemia, and nephropathy. ${ }^{2}$ The prevalence of diabetes and its complications is on the increase in part due to changes in life style. It is projected that by the year 2030, over 500 million adults will be affected by diabetes mellitus. ${ }^{3}$ The projected increase in prevalence is expected to be higher in Africa and Asia where there is rapid epidemiological transition. Treatment measures currently available for diabetes include orthodox drugs, diet control, exercise and the use of medicinal plants. Medicinal plants seem to be gaining acceptance for the management of diabetes due its fewer side effects compared to orthodox drugs. Medicinal plants contain phytochemicals that have been a pivotal pipeline for drug discovery. ${ }^{4}$ In Nigeria, there are claims that Annona muricata and Tapinanthus globiferus have anti-diabetic properties. Annona muricata is a fruit tree of the Annonaceae family also known by the names soursop, graviola and guanabana. ${ }^{5}$ Communities in Africa and South America use this plant for medicinal purposes. Use of Annona muricata for the treatment of malaria, hepatoprotection, prostate enlargment and diabetes has been scientifically substantiated. These pharmacological properties can be attributed to the abundance of phytochemicals such alkaloids, megastigmanes, triglycosides, flavonoid, phenolics, cyclopetide and essential oils in Annona muricata. ${ }^{6,7}$ These phytochemicals are believed to confer various medicinal properties on plants. Tapinanthus globiferus, a mistletoe is of the family Loranthacea native to Nigeria and Cameroon. Tapinanthus globiferus is commonly consumed for the treatment of hypertension, ulcers, poor vision, and diabetes and for promoting muscular relaxation. ${ }^{8}$ Experimental evidence reveals that Tapinanthus globiferus possess a variety of pharmacological activities. Adekunle et al., showed that Tapinanthus globiferus extracts

Cite this article: Atanu FO, Avwioroko OJ, Ilesanmi OB, Oguche M. Comparative Study of the Effects of Annona muricata and Tapinanthus globiferus Extracts on Biochemical Indices of Diabetic Rats. Pharmacog J. 2019;11(6):1365-70. 
possessed anti-inflammatory properties evidenced by marked reduction in serum levels of TNF- $\alpha$ and IL-2 in animals. ${ }^{9}$ They also reported that Tapinanthus globiferus reduced lipid peroxidation in acetaminophen induced oxidative stress rat model. ${ }^{9}$ In a similar experiment by Abubakar et al., the stimulatory effect of Tapinanthus globiferus on antioxidant enzymes in rats was reported. ${ }^{10}$ These pharmacological benefits could be explained by the rich antioxidant contents evidenced by the ability to scavenge free radicals and inhibit lipid peroxidation. ${ }^{11}$ Therefore, the present study was designed to compare the benefits of the two plants in combating the complications of diabetes on one hand, and on the other hand establish the benefits or otherwise of the combination of both plants.

\section{MATERIALS AND METHODS}

\section{Plant collection and extraction}

Fresh young leaves of Annona muricata and Tapinanthus globiferus plants were collected in the month of June from Anyigba, Kogi State, Nigeria. The leaves were dried until constant weight was achieved and thereafter pulverized. Extraction of pulverized leaves was done with methanol at room temperature for 2 days in accordance with previously published studies but minor modifications. ${ }^{12,13}$ The filtrate was concentrated in a rotary evaporator.

\section{Laboratory animals}

Forty eight (48) male albino rats weighing between 180 - 200 g were used for this study. The animals were maintained in appropriate laboratory conditions $\left(25 \pm 3^{\circ} \mathrm{C}\right.$ temperature and 12 -hr dark-12-hr light cycle) and fed rat chow and water ad libitum.

\section{Induction of diabetes and experimental design}

Diabetes was induced by a single intraperitoneal injection of freshly prepared alloxan monohydrate at a dose of $150 \mathrm{mg} / \mathrm{kg} \mathrm{BW}$. After two (2) days blood was taken from the tail through a lancet cut and blood glucose levels were measured using a Glucometer. Rats with fasting blood glucose levels $\geq 250 \mathrm{mg} / \mathrm{dl}$ were considered to be diabetic. Normal non-diabetic rats were used as control (group I). The diabetic rats were randomly assigned to seven (7) groups as follows: Diabetic untreated (group II), Metformin treatment (group III), Annona muricata 200 $\mathrm{mg} / \mathrm{kg}$ BW treatment (group IV), Annona muricata $400 \mathrm{mg} / \mathrm{kg}$ BW treatment (group V), Tapinanthus globiferus $200 \mathrm{mg} / \mathrm{kg} \mathrm{BW}$ treatment (group VI), Tapinanthus globiferus $400 \mathrm{mg} / \mathrm{kg} \mathrm{BW}$ treatment (group VII), diabetic rats receiving Annona muricata + Tapinanthus globiferus $200 \mathrm{mg} / \mathrm{kg} \mathrm{BW}$ each (group VIII). The treatments were administered once a day for 21 days. The concentrations of plant extracts and drugs used in this study are similar to safe and effective doses used in earlier studies. ${ }^{5,14}$

\section{Biochemical tests}

On the $22^{\text {nd }}$ day being the day after the last treatment, animals were sacrificed and blood was collected. Serum was prepared from whole by a low speed centrifugation at 3,000 rpm for 10 minutes. Blood lipids namely, TC, HDL and TG and markers of kidney damage namely, creatinine and urea were estimated using Randox diagnostic kits according to the manufacturer's protocols. Atherogenic index was calculated according to the method of Ojiako et al., using the formula ${ }^{15}$ :

Atherogenic Index $=[\mathrm{TC}-\mathrm{HDL}-\mathrm{c}] / \mathrm{HDL}-\mathrm{c}$

\section{Data analysis}

Results were expressed as Means \pm SD. Differences among experimental groups were analyzed by Analysis of Variance (ANOVA) using SPSS 16.0. Differences among groups were considered significant when $p<0.05$.

\section{RESULTS AND DISCUSSION}

This study was designed to compare the benefits of methanol extracts of Annona muricata and Tapinanthus globiferus in the management of dyslipidemia and nephropathy using the alloxan diabetes rat model. Alloxan induces insulin dependent diabetes through reactive oxygen species (ROS) mediated destruction of pancreatic $\beta$-cells leading to hyperglycemia and derangement of several metabolic pathways. ${ }^{16}$ Administration of alloxan at dose of $150 \mathrm{mg} / \mathrm{kg}$ BW caused significant alterations in thelipid profile and indices of kidney function in conformity with earlier studies which utilised alloxan for creating animal models of hyperlipidemia and nephropathy. ${ }^{7,14}$ Figure 1 shows the effects of AME and TGE on the lipid profile of diabetic rats. AME and TGE caused a dose dependent reduction of the levels of TC when compared with diabetic untreated rats whose TC levels were elevated by alloxan. In fact, AME at $400 \mathrm{mg} / \mathrm{kg} \mathrm{BW}$ produced a reduction of TC commensurate to the standard anti-diabetic drug metformin. The reduction was however, more pronounced in the group treated with AME than in the TGE group. A similar trend was observed in the TG levels of AME and TGE treated diabetic rats when compared with the negative control. These results are in consonance with available published evidence on the antihyperlipidemic, anti-hyperglycaemic potentials of AME and TGE., ${ }^{5,17}$ In other related works it was reported that AME and TGE could protect serum and brain lipids from peroxidation through the enhancement of antioxidant enzyme levels. ${ }^{10-18}$ The most common lipid abnormalities in diabetes are hypertriglyceridemia and hypercholesterolemia. The increase in the levels of serum levels of cholesterol and triglycerides in the diabetic rats is a result of insulin deficiency and altered activity of enzymes such as lipases and lecithin cholesterol acyl transferase (LCAT) for regulation of blood lipids. Indeed, there is evidence to show that AME stimulates the release of insulin and restoration of pancreatic cells which could be responsible for the reversal of hyperlipidaemia. ${ }^{5,13,18}$ Attenuation of the alteration in levels of serum lipids reveals that AME and TGE have anti-hyperlipidaemia properties that could protect against cardiovascular complications. Decreased serum levels of TC could be attributed to increased fecal excretion of cholesterol or decreased activity of 3-hydroxy-3-methylglutarylcoenzyme (HMG$\mathrm{CoA})$ reductase and acyl CoA cholesterol acyltransferase (ACAT). Conversely, the concentrations of HDL declined upon induction of diabetes with alloxan. The inverse relationship between TG and HDL has been established by existing literature. AME and TGE ameliorated the decline in serum HDL levels; AME at $400 \mathrm{mg} / \mathrm{kg}$ BW was the most effective with its potency comparable to the standard anti-diabetic drug metformin. High levels of HDL connote an improved cardiovascular health because HDL is responsible for removal of cholesterol from the blood through a mechanism known as reverse cholesterol transport.

The calculated atherogenic index (AI) is a measure of predisposition of animals to developing atherosclerosis; high AI signifies a tendency to develop atherosclerosis. Obviously, there was escalation of AI about thirty (30) folds in diabetic untreated rats when compared to normal control rats (Table 1). Rats treated with AME and TGE however, showed promising reduction in $\mathrm{AI}$, this corroborates the studies of Agbai et al. in which AME increased the anti-atherogenic index of diabetic rats evidenced by reduction in the aortic wall thickening. ${ }^{19}$

Morbidity and mortality resulting from diabetic nephropathy is common among diabetic patients. Its symptoms include increased catabolism of proteins, altered glomerular filtration and hike in the concentrations of creatinine, urea and electrolyte concentrations. In the present study creatinine and urea were assayed in order to access the kidney function. Creatinine and urea serum levels drastically increased in diabetic rats which were decreased by treatment with AME and TGE as shown in Figure 2. Again, AME proved to be more efficacious than TGE in managing the kidney function indices of diabetic rats. These 
(a)

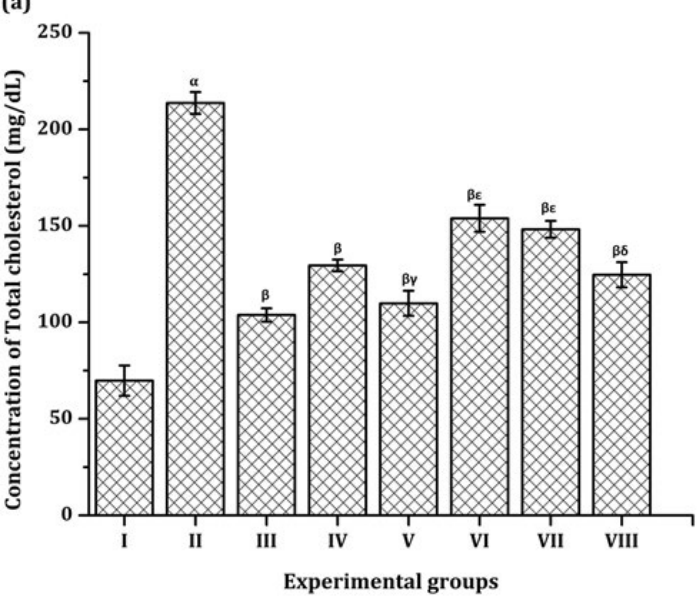

(b)

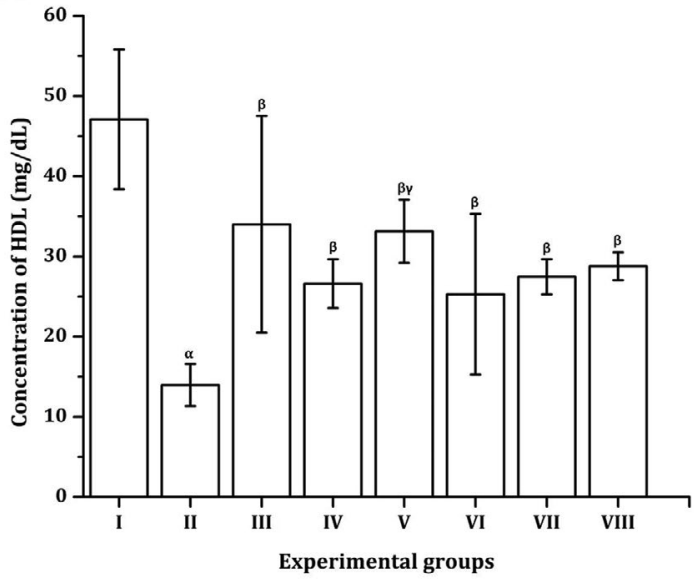

(c)

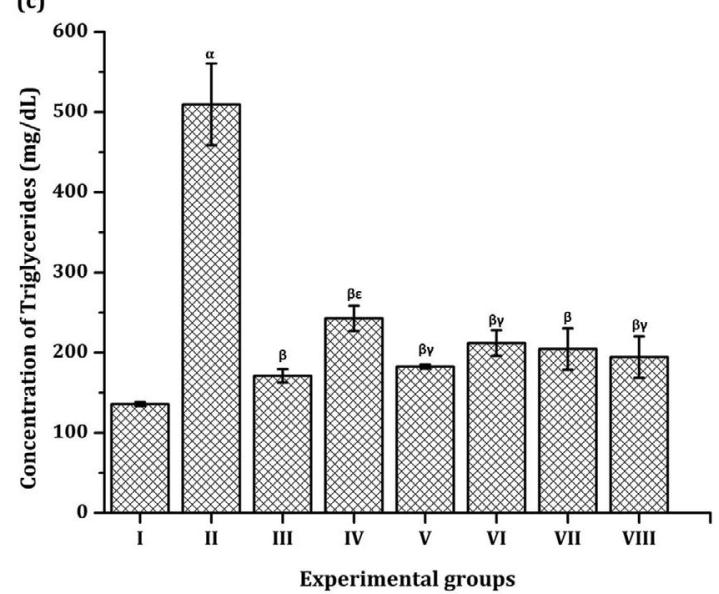

Figure 1: Effects of Annona muricata and Tapinanthus globiferus extracts on (a) Total cholesterol, (b) High density lipoprotein and (c) Triglycerides of alloxan diabetic rats.

Animal grouping: I - Normal control, II - Diabetic untreated, III - Metformin, IV - Annona muricata 200 mg/kg BW, V - Annona muricata 400 mg/kg BW, VI - Tapinanthus globiferus 200 mg/kg BW, VII - Tapinanthus globiferus $400 \mathrm{mg} / \mathrm{kg} \mathrm{BW,} \mathrm{VIII} \mathrm{-} \mathrm{Annona} \mathrm{muricata} \mathrm{+}$ Tapinanthus globiferus 200mg/kg BW each.

Values are Means $\pm S D(n=6)$. ${ }^{a} p<0.05$ compared to normal control group; ${ }^{\beta} \mathrm{p}<0.05$ compared to diabetic untreated group; ${ }^{\gamma} \mathrm{p}<0.05$ compared to Annona muricata $200 \mathrm{mg} / \mathrm{kg}$ BW group; ${ }^{\delta} \mathrm{p}<0.05$ compared to Tapinanthus globiferus $200 \mathrm{mg} / \mathrm{kg}$ BW group; ${ }^{\varepsilon} \mathrm{p}<0.05$ compared to the Annona muricata + Tapinanthus globiferus. 
evidences are supported by other works where AME lowered the upswing in serum electrolytes and other markers of kidney damage. ${ }^{18,20}$ Although it is not clear the reason for the elevated creatinine levels of rats in Group VI treated with $200 \mathrm{mg} / \mathrm{kg}$ BW of TGE. A plausible explanation could be increased muscle degradation leading to elevated serum levels of creatinine.
Overall, combinations of AME + TGE provided prove of principle that co-administration of medicinal products could offer some synergistic or additive effects. Interestingly, in the present study, the group treated with both AME and TGE had improved biochemical indices than the groups treated with a single plant. There have been similar results from efforts of scientists to treat diabetes with

Table 1: Effects of Annona muricata and Tapinanthus globiferus extracts on Atherogenic index of diabetic rats.

\begin{tabular}{cc}
\hline Groups & Atherogenic index (Al) \\
\hline Normal untreated & 0.48 \\
Diabetic untreated & 14.31 \\
Metformin $100 \mathrm{mg} / \mathrm{kg} \mathrm{BW}$ & 2.05 \\
Annona muricata $200 \mathrm{mg} / \mathrm{kg} \mathrm{BW}$ & 3.87 \\
Annona muricata $400 \mathrm{mg} / \mathrm{kg} \mathrm{BW}$ & 3.31 \\
Tapinanthus globiferus $200 \mathrm{mg} / \mathrm{kg} \mathrm{BW}$ & 5.09 \\
Tapinanthus globiferus $400 \mathrm{mg} / \mathrm{kg}$ BW & 4.40 \\
Annona muricata + Tapinanthus globiferus \\
$200 \mathrm{mg} / \mathrm{kg}$ BW each
\end{tabular}

(a)

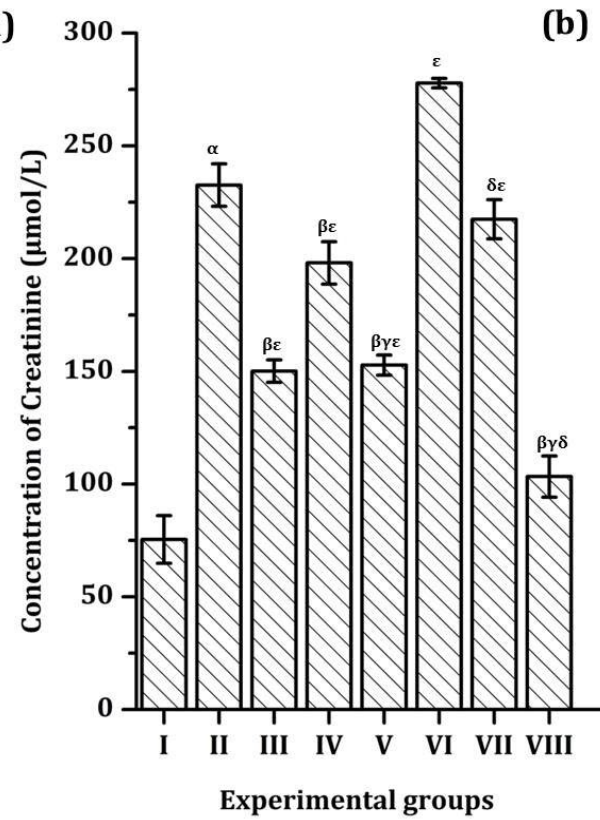

(b)

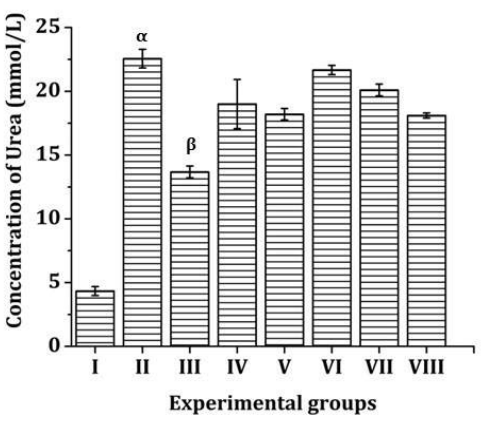

Figure 2: Effects of Annona muricata and Tapinanthus globiferus extracts on plasma (a) Creatinine and (b) Urea levels in diabetic rats.

Animal grouping: I - Normal control, II - Diabetic untreated, III - Metformin, IV - Annona muricata $200 \mathrm{mg} / \mathrm{kg} \mathrm{BW}, \mathrm{V}$ - Annona muricata $400 \mathrm{mg} / \mathrm{kg} \mathrm{BW}, \mathrm{VI}$ - Tapinanthus globiferus $200 \mathrm{mg} / \mathrm{kg} \mathrm{BW}$, VII - Tapinanthus globiferus 400 mg/kg BW, VIII - Annona muricata + Tapinanthus globiferus $200 \mathrm{mg} / \mathrm{kg}$ BW each.

Values are Means $\pm S D(n=6) .{ }^{a} p<0.05$ compared to normal control group; ${ }^{\beta} p<0.05$ compared to diabetic untreated group; ${ }^{\gamma} \mathrm{p}<0.05$ compared to Annona muricata $200 \mathrm{mg} / \mathrm{kg}$ BW group; ${ }^{\delta} \mathrm{p}<0.05$ compared to Tapinanthus globiferus $200 \mathrm{mg} / \mathrm{kg}$ BW group; $\varepsilon^{\varepsilon}<0.05$ compared to the Annona muricata + Tapinanthus globiferus. 
combination of two or more plants. ${ }^{15,21}$ For instance combinations of Tapinanthus globiferus + Treculia africana and Annona muricata + Artocarpus heterophyllus were more potent at arresting diabetic nephropathy, hyperglycemia and hyperlipidemia than any of the plants used alone. ${ }^{14,20}$ In summary, the results here presented could be attributed to the positive effects of the phytochemical components of the extracts used for this study. This assertion is buttressed by the works of Nguegium et al. and Ogunbolude et al. which showed that AME and TGE are rich in bioactive phytochemicals which are known to have several health benefits including the management of diabetes and other metabolic diseases. ${ }^{18,22}$

\section{CONCLUSION}

The findings of this study suggest that Annona muricata and Tapinanthus globiferus are effective in treatment of experimental diabetes. Combination of the two plants improved the biochemical indices of diabetic animals.

\section{REFERENCES}

1. Oputa RN, Chinenye S. Diabetes mellitus: A global epidemic with potential solution. African Journal of Diabetes Medicine. 2012;20(2):33-5.

2. Gakidou E, Mallinger L, Abbott-Klafter J, Guerrero R, Villalpando S, Ridaura $\mathrm{RL}$, et al. Management of diabetes and associated cardiovascular risk factors in seven countries: a comparison of data from national health examination surveys. Bulletin of the World Health Organization. 2011;89(3):172-83.

3. Anna V, van der Ploeg HP, Cheung NW, Huxley RR, Bauman AE. Sociodemographic correlates of the increasing trend in prevalence of gestational diabetes mellitus in a large population of women between 1995 and 2005. Diabetes Care. 2008;31(12):2288-93.

4. Abubakar K, Adebisi IM, Ugwah-Oguejiofor JC, Idris GO, Idris B, Mshelia HE. Phytochemical screening and anticonvulsant activity of the residual aqueous fraction of Tapinanthus globiferus growing on Ficus glumosa. Herb Med. 2016;2(2):1-6.

5. Adewole SO, Caxton-Martins EA. Morphological changes and hypoglycemic effects of Annona muricata Linn. (Annonaceae) leaf aqueous extract on pancreatic $\beta$-cells of streptozotocin-treated diabetic rats. Afr. J Biomed Res. 2006;9:173-87.

6. Leboeuf M, Cave A, Bhaumik P, Mukherjee B, Mukherjee R. The phytochemistry of the Annonaceae. Phytochemistry. 1980;21:2783-813.

7. Atanu FO, Momoh S, Ugwu CE, Ameh O, Suleiman MS. Amelioration of histological changes and associated metabolic abnormalities by a combination of Morinda lucida and metformin in diabetic rats. J Phytopharmacol. 2018;7(3):253-6.

8. Edem DO, Usoh IF. Biochemical changes in Wistar Rats on oral doses of mistletoe (Loranthus micranthus). American Journal of Pharmacology and Toxicology. 2009;4(3):94-7.
9. Adekunle AS, Oyewo BE, Afolabi OK. Therapeutic efficacy of Tapinanthus globiferus on acetaminophen induced nephrotoxicity, inflammatory reactions and oxidative stress in albino rats. Int Res J Biochem Bioinform. 2012;2(2):41-5.

10. Abubakar K, Yunus AT, Abubakar MR, Ugwah-Oguejiofor JC, Muhammad AA. Antioxidant and antikindling effect of Tapinanthus globiferus growing on Ficus glumosa in pentylenetetrazole induced kindled rats. Afr J Biotechnol. 2018;17(4):73-80.

11. Oche J-R I, Johnson TO, Akinsanmi AO, Jaryum KH, Francis T. In vitro antioxidant activity and inhibition of $\mathrm{Fe} 2+$ and SNP lipid peroxidation of African mistletoes (Tapinanthus globiferus) from three selected host plants in jos plateau state Nigeria. Journal of Applied Life Sciences International. 2019;20(4):1-10.

12. Adeyemi D, Komolafe O, Adewole S, Obuotor E. Anti Hyperlipidemic activities of Annona Muricata (Linn). The Internet Journal of Alternative Medicine. 2008;7(1):1-7.

13. Adeyemi DO, Komolafe OA, Adewole OS, Obuotor EM, Adenowo TK Anti-hyperglycemic activities of Annona muricata (linn). Afr J Trad CAM 2009;6(1):62-9.

14. Ogbonnia SO, Anyika EN, Mbaka GO, Utah P, Ugwu D, Nwakakwa N, Ota DA. Antihyperglycaemic and antihyperlipidaemic effects of aqueous ethanol extract of Tapinanthus globiferus leaves and Treculia africana root bark and their mixture on alloxan diabetic rats. Agric Biol J N Am. 2012;3(6):237-46.

15. Ojiako OA, Chikezie PC, Ogbuji AC. Blood glucose level and lipid profile of alloxan-induced hyperglycemic rats treated with single and combinatorial herbal formulations. J Tradit Complement Med 2015;6(2):184-92.

16. Radenković M, Stojanović M, Prostran M. Experimental diabetes induced by alloxan and streptozotocin: The current state of the art. Journal of Pharmacological and Toxicological Methods. 2016;78:13-31.

17. Adewole SO, Ojewole JAO. Protective effects of Annona muricata linn. (annonaceae) leaf aqueous extract on serum lipid profiles and oxidative stress in hepatocytes of streptozotocin-treated diabetic rats. Afr J Trad CAM. 2009;6(1):30-41.

18. Ngueguim TF, Massa ZB, Kouamouo J, Tchuidjang A, Dzeufiet DPD Kamtchouing P, Dimo T. Antidiabetic and antioxidant effects of Annona muricata (Annonaceae), aqueous extract on streptozotocin-induced diabetic rats. Journal of Ethnopharmacology. 2014;151:784-90.

19. Agbai EO, Njoku CJ, Nwanegwo CO, Nwafor A. Effect of aqueous extract of Annona muricata seed on atherogenicity in streptozotocin-induced diabetic rats. Afr J Pharm Pharmacol. 2015;9(30):745-55.

20. Onuah CL, Uwakwe AA, Anacletus FC. Combined ethanol leaf extract of Sour Sop (Anonna Muricata) and Jackfruit (Artocarpus Heterophyllus) leaves ameliorates streptozotocin Induced Type 2 Diabetes Mellitus In Wistar Albino Rats. Journal of Pharmacy and Biological Science. 2018;13(6):49-60.

21. Kaur R, Afzal M, Kazmi I, Ahamd I, Ahmed Z, Ali B, Ahmad S, Anwar F Polypharmacy (herbal and synthetic drug combination): a novel approach in the treatment of type-2 diabetes and its complications in rats. J Nat Med. 2013;67:662-71.

22. Ogunbolude $Y$, Ibrahim M, Elekofehinti OO, Adeniran A, Abolaji AO, Rocha JBT, et al. Effects of Tapinanthus globiferus and Zanthoxylum zanthoxyloides extracts on human leukocytes in vitro. Journal of Intercultural Ethnopharmacology. 2014;3(4):167-72. 


\section{GRAPHICAL ABSTRACT}

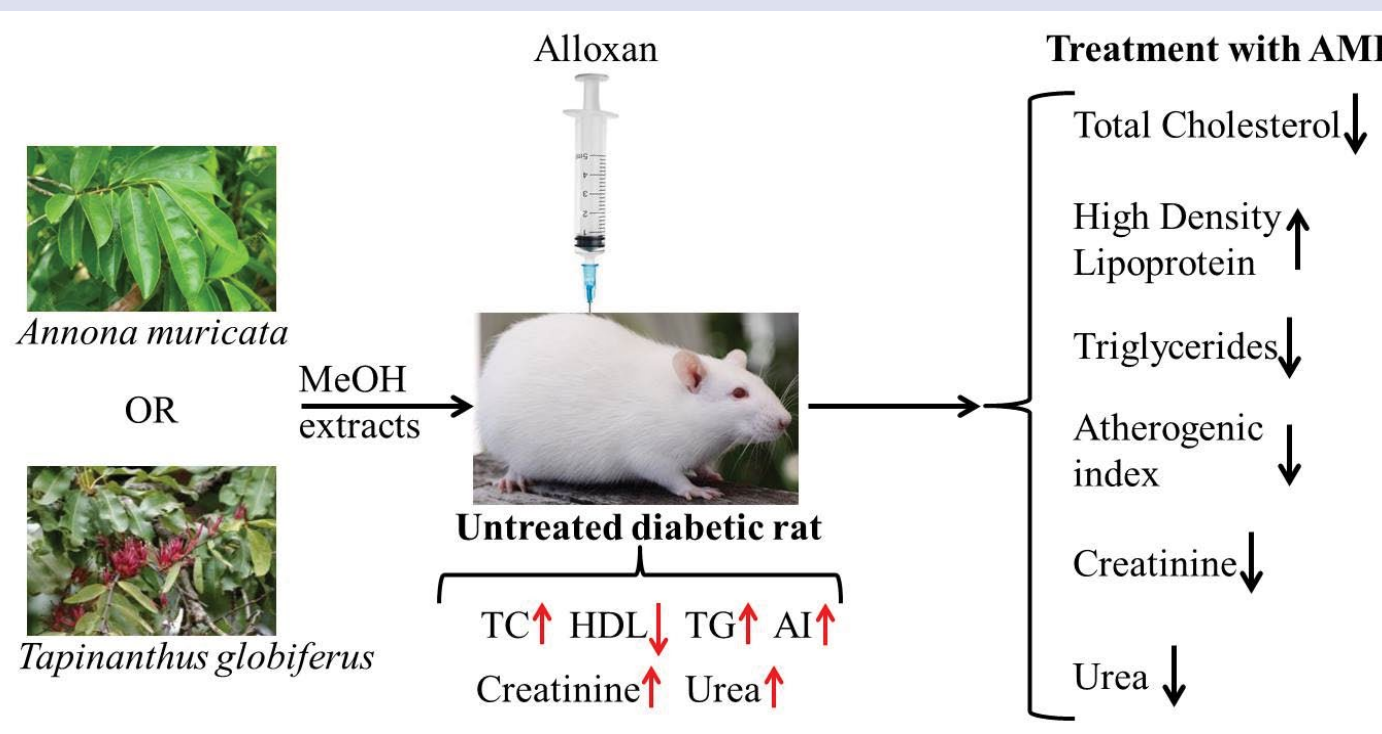

\section{RESEARCH HIGHLIGHTS}

- Alloxan caused elevation in serum levels of Total Cholesterol, Triglycerides.

- Annona muricata and Tapinanthus globiferus extracts decreased the levels of Total Cholesterol, Triglycerides in diabetic rats.

- The calculated Atherogenic index revealed that Annona muricata and Tapinanthus globiferus extracts caused improvement of cardiac health of diabetic rats.

- Kidney function was assessed by measuring serum levels of Creatinine and Urea. The results showed that Annona muricata and Tapinanthus globiferus extracts suppressed the elevation of kidney function markers caused by alloxan in diabetic rats.

- Comparative analysis of the effects of Annona muricata and Tapinanthus globiferus extracts reveals that the former was more effective at combating the indices of diabetes.

- In most cases, combination of the two plants was more effective at combating diabetic complications than any of the plants used alone.

\section{ABOUT AUTHORS}

Francis O. Atanu earned his PhD from the University of Reading, United Kingdom. He works currently as a Lecturer/Researcher at the Department of Biochemistry, Kogi State University, Nigeria. His areas of interest are Phytomedicine, Molecular and Structural Biology.

Oghenetega J. Avwioroko obtained his PhD in Biochemistry at the Delta State University, Nigeria. He currently lectures at the Department of Chemical Sciences, College of Natural Sciences, Redeemer's University, Nigeria. His research interests are Phytomedicine, Enzymology and Molecular Biology.

Omotayo O. Ilesanmi is a Lecturer/Researcher at the Federal University of Otuoke, Nigeria. He completed his PhD at the Lagos State University, Nigeria. His research interests are Drug Metabolism and Molecular Toxicology.

Mercy Oguche is a PhD candidate interested in Nutritional Biochemistry. She completed her MSc in Biochemistry at the Ahmadu Bello University, Nigeria. She is a Lecturer at the Department of Biochemistry, Kogi State University, Nigeria.

Cite this article: Atanu FO, Avwioroko OJ, Ilesanmi OB, Oguche M. Comparative Study of the Effects of Annona muricata and Tapinanthus globiferus Extracts on Biochemical Indices of Diabetic Rats. Pharmacog J. 2019;11(6):1365-70. 